\begin{tabular}{|c|c|c|c|c|c|c|}
\hline \multirow{4}{*}{ Impact Factor: } & ISRA (India) & $=3.117$ & SIS (USA) & $=0.912$ & ICV (Poland) & $=6.630$ \\
\hline & ISI (Dubai, UAE & $=0.829$ & РИНЦ (Russia & $=0.156$ & PIF (India) & $=1.940$ \\
\hline & GIF (Australia) & $=0.564$ & ESJI (KZ) & $=8.716$ & IBI (India) & $=4.260$ \\
\hline & JIF & $=1.500$ & SJIF (Moroccc & $=5.667$ & OAJI (USA) & $=0.350$ \\
\hline
\end{tabular}

\section{SOI: 1.1/TAS DOI: 10.15863/TAS International Scientific Journal Theoretical \& Applied Science}

\author{
p-ISSN: 2308-4944 (print) e-ISSN: 2409-0085 (online) \\ Year: 2019 Issue: $04 \quad$ Volume: 72
}

Published: $30.04 .2019 \quad$ http://T-Science.org
QR - Issue
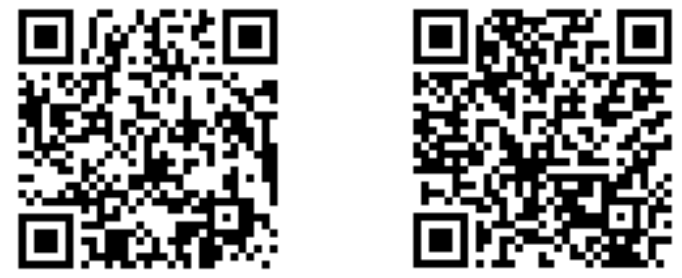

Iroda Bakiyeva

Associate Professor of Department of Business and Entrepreneurship, Financial Institution of Tashkent

Nodira Shavkatova Student of International Tourism Department Tashkent State University of Economics

Asilbek Ikromov Student of International Tourism Department Tashkent State University of Economics

\title{
TRANSPARENT INVESTMENT POLICY IS INCLUSIVE ECONOMIC GROWTH IN UZBEKISTAN
}

\begin{abstract}
In transition period of Republic of Uzbekistan diversifies whole economy to attract foreign direct investment in the country. Innovation economic process moves forward overall sustainable growth of the economy. The article discusses the principles of the investment policy of Uzbekistan with various changes for the past decades. It was determined that a priority for the country is to create a favorable investment climate in order to increase the competitiveness of the country's economy under the cooperation with international economic institutions. However, investors own considerations and viewpoints about current investment policy of Uzbekistan analyzed to prove updated legislative reforms and investment climate profile developing business environment in the country.

Key words: transition, investment attractiveness, investors, international cooperation, lending.

Language: English

Citation: Bakiyeva, I., Shavkatova, N., \& Ikromov, A. (2019). Transparent investment policy is inclusive economic growth in Uzbekistan. ISJ Theoretical \& Applied Science, 04 (72), 447-454.

Soi: http://s-o-i.org/1.1/TAS-04-72-55 Doi: crossef https://dx.doi.org/10.15863/TAS.2019.04.72.55
\end{abstract}

\section{INTRODUCTION}

Uzbekistan is taking active steps to create a favorable investment climate. This is based on two fundamental factors: political stability and a wellconsidered, balanced macroeconomic policy. Enterprises with foreign investment operate in almost all sectors of the national economy, but the maximum gross product produced by such enterprises was obtained in mechanical engineering, food industry, non-ferrous metallurgy, in trade and public catering. To date, more than 3,200 enterprises have been registered in Uzbekistan, created with the participation of investors from more than 85 countries of the world [1].

The largest number of enterprises with foreign investments was created with the participation of investors from Russia, China, South Korea, Turkey, the United States, Great Britain and Germany. The level of economic development of any state largely depends on foreign investment. In Uzbekistan, appropriate measures are being taken in order to interest potential investors to invest in the economy of the republic. But to achieve the proper effect is not easy as accounted. Foreign investors are extremely careful and seek to eliminate any risks when investing their capital in any project. They need business guarantees that will not only remain safe and, but will also make profit.

\section{URGENCY}

In order to improve the business environment government of Uzbekistan made a number of legislative changes in 2017, including the repeal of unplanned and seemingly arbitrary or punitive controls on companies from 1 January 2017. Annulment of the obligation to convert certain percentages of hard currency export earnings into official exchange rate; Simplification of business registration procedures; Creation of an office of the 


\begin{tabular}{|c|c|c|c|c|c|c|}
\hline \multirow{4}{*}{ Impact Factor: } & ISRA (India) & $=3.117$ & SIS (USA) & $=0.912$ & ICV (Poland) & $=6.630$ \\
\hline & ISI (Dubai, UAE & $=0.829$ & РИНЦ (Russia & $=\mathbf{0 . 1 5 6}$ & PIF (India) & $=1.940$ \\
\hline & GIF (Australia) & $=0.564$ & ESJI (KZ) & $=8.716$ & IBI (India) & $=4.260$ \\
\hline & JIF & $=1.500$ & SJIF (Morocco & $=5.667$ & OAJI (USA) & $=0.350$ \\
\hline
\end{tabular}

economic ombudsman; and the Anti-Corruption Law, which seeks to increase the transparency of the activities of the Government of Uzbekistan. Foreign investors are welcome in all areas of the Uzbek economy and the government cannot discriminate against foreign investors by nationality, place of residence or country of origin. State control of key industries, however, has a discriminatory impact on foreign investors. For example, the Uzbek Government maintains strict control over all economic processes and retains control in key sectors such as energy, telecommunications, airlines and mining. From these point of views our research is relevant.

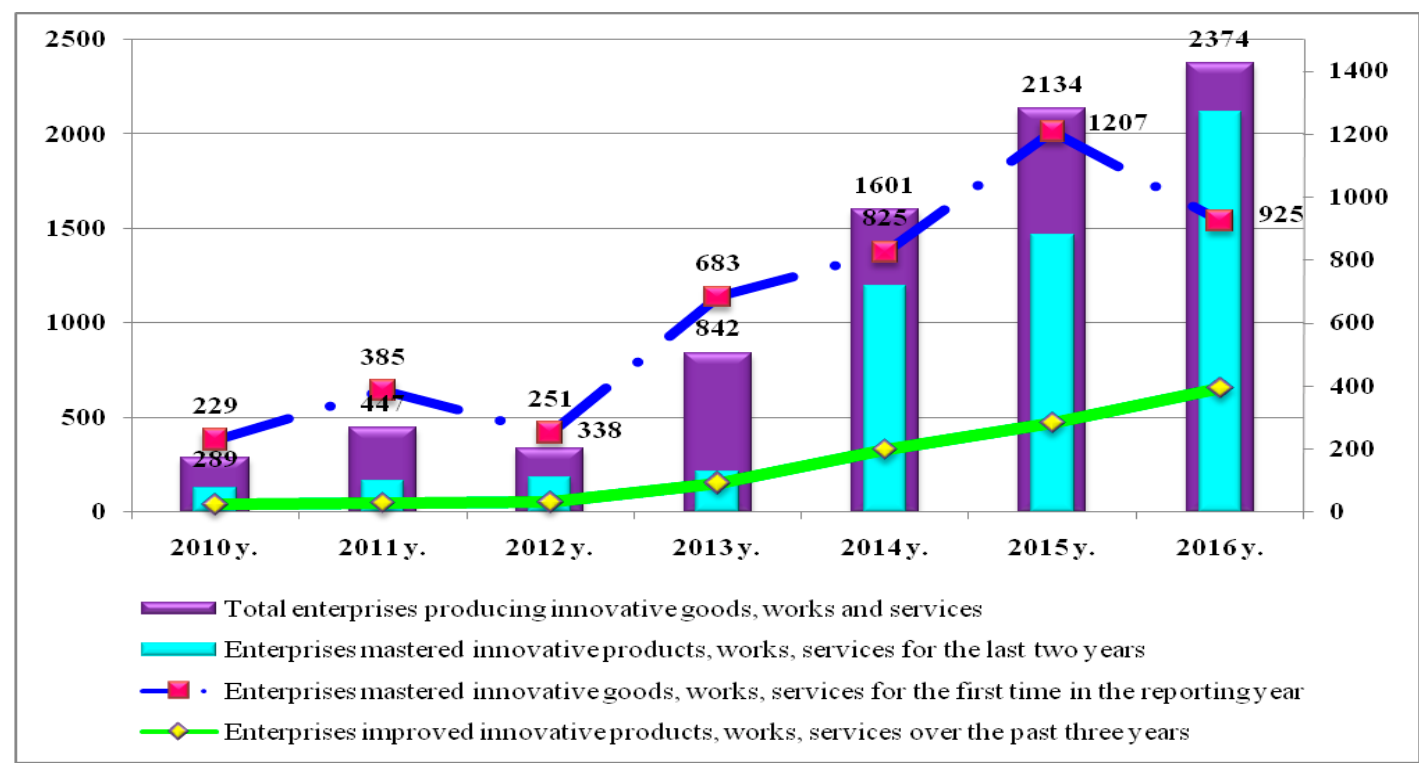

Diagram1. Number of enterprises and organizations producing innovative goods, works and services (2010-2016)

Source: official date of stat.uz

\section{ANALYTICAL PART}

The number of enterprises and organizations producing innovative goods, works and services grew up 8 times from 2010 to 2016 from 289 to 2374 units. Enterprises that first mastered the production of innovative products, works and services increased by 696 units [2].

Currently many Programs for the Development of the Regions of the countries are directly tied to hidden reserves, which is generally consistent with the goals and objectives of the development of the territories. In the next part we will address major factors cooperation projects.

The aims of the Development program are to:

- Raise awareness of development issues in countries.

- Promote debate on interlinked political, economic and social matters.

- Bring together political authorities, members of national, international and European development organizations, and business representatives.
Uzbekistan: Country Operations Business Plan (2018-2020)

The country partnership strategy (CPS), 20122016 of the Asian Development Bank (ADB) for Uzbekistan supported infrastructure development and access to finance. Consultations with the government confirmed that the strategic focus of the CPS remains valid. The proposed country operations business plan (COBP), 2018-2020 for Uzbekistan extends the validity of the CPS, and is consistent with recent government initiatives. This COBP fully supports the strategy and reflects updated development priorities of Uzbekistan. To this end, this COBP includes operational support for transport, energy, municipal services, health, and access to finance. Support for the key drivers of changeprivate sector development, regional cooperation, knowledge management, gender equity, and climate change and the environment-is integrated into the operational assistance [3].

If we analyze current approaches we will come following feedback from foreign investors:

- Uzbekistan is situated in the center of Central Asia

- Uzbekistan is double-landlocked 


\begin{tabular}{|c|c|c|c|c|c|c|}
\hline \multirow{4}{*}{ Impact Factor: } & ISRA (India) & $=3.117$ & SIS (USA) & $=0.912$ & ICV (Poland) & $=6.630$ \\
\hline & ISI (Dubai, UAE & $=0.829$ & РИНЦ (Russia & $=\mathbf{0 . 1 5 6}$ & PIF (India) & $=1.940$ \\
\hline & GIF (Australia) & $=0.564$ & ESJI (KZ) & $=8.716$ & IBI (India) & $=4.260$ \\
\hline & JIF & $=1.500$ & SJIF (Morocco & $=5.667$ & OAJI (USA) & $=0.350$ \\
\hline
\end{tabular}

- Uzbekistan offers young and generally welleducated workforce

- Uzbekistan is a very attractive consumer market with $33 \mathrm{mln}$. population
- Transport and communication systems are well developed [4].

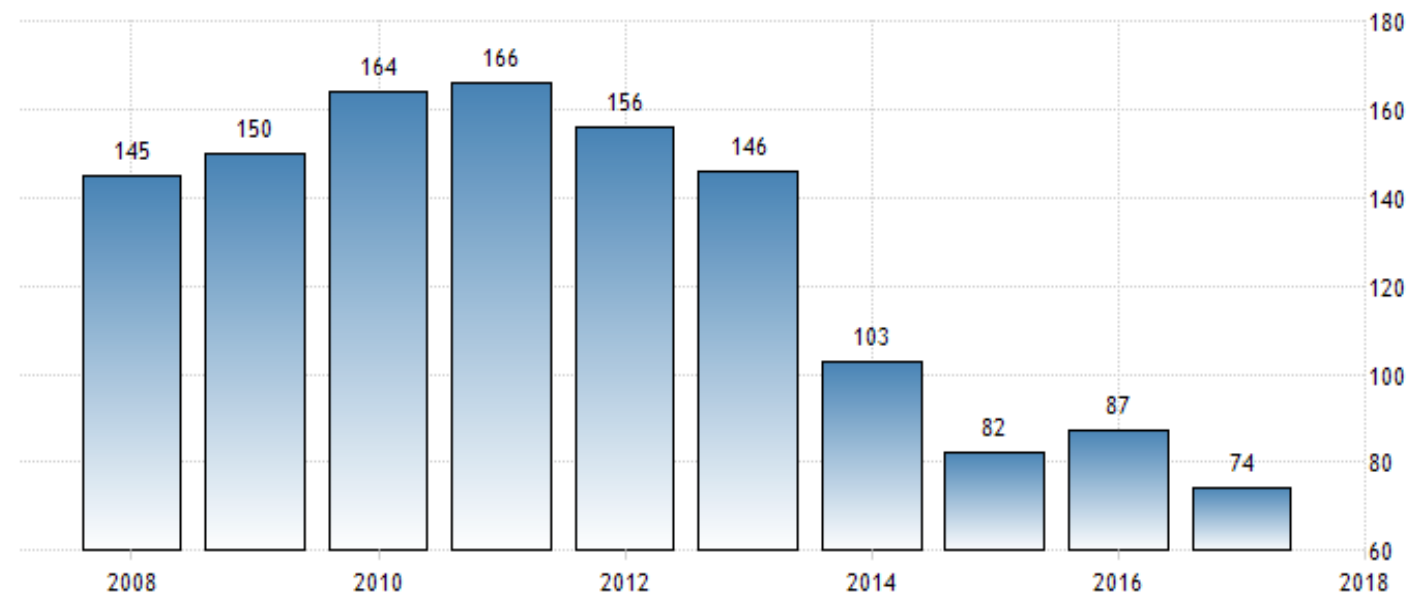

Diagram 2. Ease of Doing Business in Uzbekistan (2008-2018)

\section{Source: Official data of trading economics}

For the development and regulations of the foreign investment activity highly relevant creation of the National Agency for Project Management under the President of Uzbekistan (NAPU) in Uzbekistan. "For example, any investor, before investing his capital in the economy of Uzbekistan, first of all, according to various sources, studies the state of the business environment in the republic. And one of such authoritative sources is the report of the World Bank and the International Finance Corporation "Doing Business".

As for the Trading Economics Uzbekistan is ranked 74 among 190 economies in the ease of doing business, according to the latest World Bank annual ratings. The rank of Uzbekistan improved to 74 in 2017 from 87 in 2016. Ease of Doing Business in Uzbekistan averaged 127.30 from 2008 until 2017, reaching an all-time high of 166 in 2011 and a record low of 74 in 2017.

\section{Regulations for business authorities}

Uzbekistan has a highly regulated economy with a vast number of regulatory authorities. The principal regulatory authorities are the Cabinet of Ministers (responsible for the overall regulation of the economy), the Ministry of Finance (responsible for fiscal and taxation policy), the Central Bank (responsible for regulation of banks and monetary policy), the State Tax Committee (responsible for collection of taxes), the State Customs Committee (responsible for collection of customs payments), the Ministry of Economy (responsible for development and implementation of long-term social and economic strategies of the state) and the Ministry of Foreign Economic Relations, Investment and Trade (responsible for foreign trade and attraction of foreign investment) [5]. 


\begin{tabular}{|c|c|c|c|c|c|c|}
\hline \multirow{4}{*}{ Impact Factor: } & ISRA (India) & $=3.117$ & SIS (USA) & $=0.912$ & ICV (Poland) & $=6.630$ \\
\hline & ISI (Dubai, UAE & $=0.829$ & РИНЦ (Russia & $=\mathbf{0 . 1 5 6}$ & PIF (India) & $=1.940$ \\
\hline & GIF (Australia) & $=0.564$ & ESJI (KZ) & $=8.716$ & IBI (India) & $=4.260$ \\
\hline & JIF & $=1.500$ & SJIF (Morocco & $=5.667$ & OAJI (USA) & $=0.350$ \\
\hline
\end{tabular}

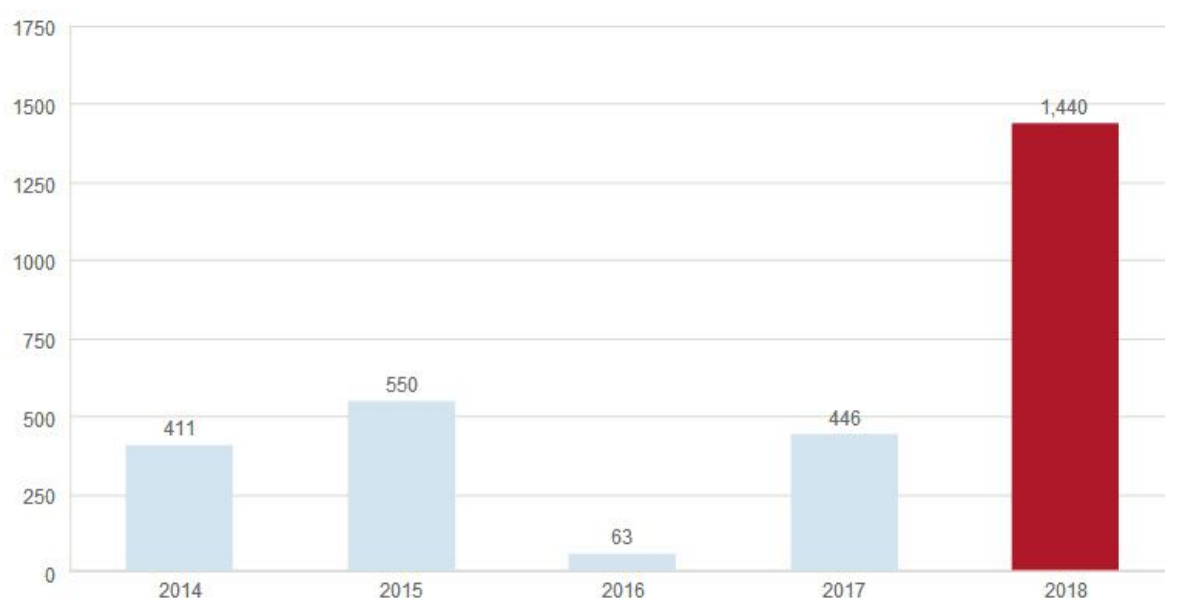

Figure 3. Uzbekistan: Commitments by Fiscal Year (in millions of dollars) [6].

\section{Source: Official data of the World Bank}

Liberalization of financial sector is a greater independence for the Central Bank of Uzbekistan (CBU), an assessment of banking sector resilience, the implementation of financial recovery plans (SOEs), and plans to reinitiate the previously stalled World Trade Organization.

Loans allocated by local banks participating in the project have funded business activities across the country, affecting a larger pool of horticultural producers and 12,000 farmers by providing improved access to services and facilities or inputs such as seedlings, fruits total of 223 loans have been issued co-invested US\$52.3 million equivalent of their own funds, bringing the total amount of investments in the agricultural sector to US $\$ 185$ million. Following table states that total lending money from World Bank for long term development projects [7].

\begin{tabular}{|ll|}
\hline Number of active projects & 16 \\
IBRD & US $\$ 2.7$ billion \\
IDA & US $\$ 1.2$ billion \\
\hline
\end{tabular}

Figure 4. World Bank Partneurship Overwiev

\section{Source: Official data of the World Bank}

Above table indicates that total investment projects in Uzbekistan cooperation with World Bank. It is seen that obtained credit lines and amounts of two main partners by 2017 .

The strategic goal of the ongoing reforms in the field of improving the investment climate has been defined, which is to create in Uzbekistan the most favorable conditions for business activities and foreign investments corresponding level of the top twenty countries of the world by 2022. It is important that in the regions they will change their attitude and turn to investors, they will begin to create all the conditions not to think about interdepartmental issues, but to think about how to increase the country's potential with the help of these investments, accelerate development and improve the image [8].

\section{Investor considerations}

- Economy is highly regulated by the state

- Low level of copyright protection

- Plenty of office space available

The role of investment attractiveness in small business and private entrepreneurship in the country's GDP and economy is gradually going up. In 2017, this sector generated $56.7 \%$ of the GDP and created $77.9 \%$ of employments to the population. 


\begin{tabular}{|c|c|c|c|c|c|c|}
\hline \multirow{4}{*}{ Impact Factor: } & ISRA (India) & $=3.117$ & SIS (USA) & $=0.912$ & ICV (Poland) & $=6.630$ \\
\hline & ISI (Dubai, UAE & $=0.829$ & РИНЦ (Russia & $=\mathbf{0 . 1 5 6}$ & PIF (India) & $=1.940$ \\
\hline & GIF (Australia) & $=0.564$ & ESJI (KZ) & $=8.716$ & IBI (India) & $=4.260$ \\
\hline & JIF & $=1.500$ & SJIF (Morocco & $=5.667$ & OAJI (USA) & $=0.350$ \\
\hline
\end{tabular}

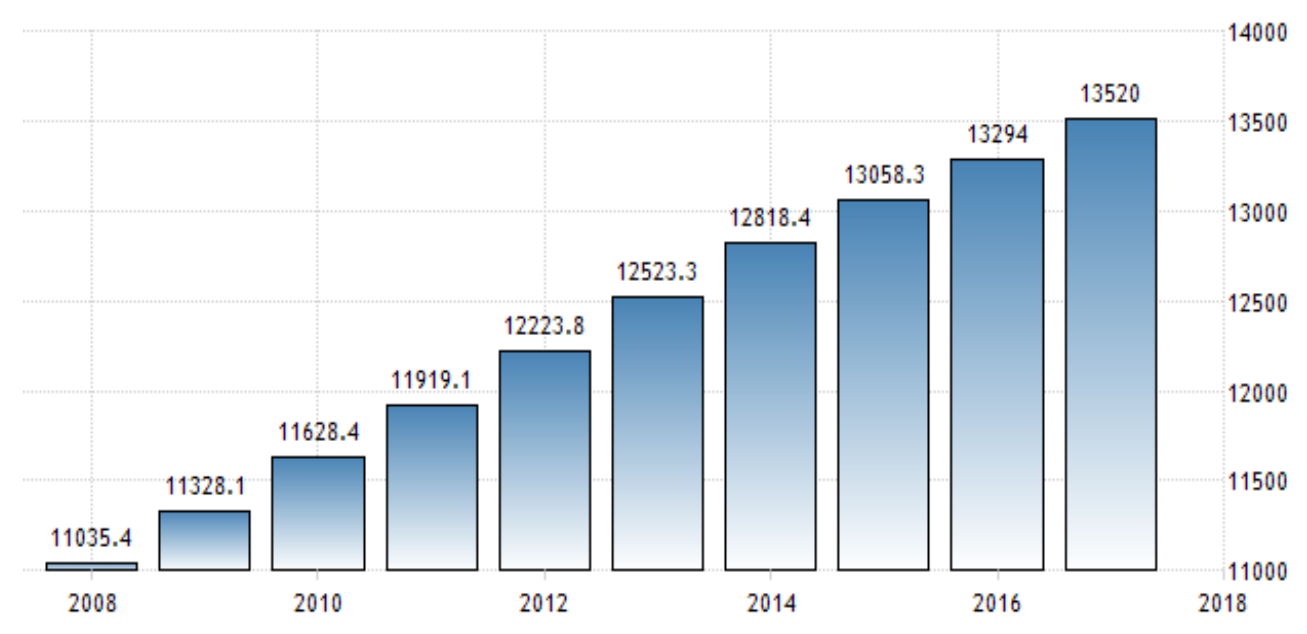

Figure 5. Uzbekistan Employed Persons (2008-2018)

Source: Official data of trading economics

The number of employed persons in Uzbekistan increased to 13520 thousand in 2017 from 13294 thousand in 2016. Employed Persons in Uzbekistan averaged 10305.11 thousand from 1991 until 2017, reaching an all-time high of 13520 thousand in 2017 and a record low of 8255 thousand in 1991 [9]. While investors hire employees in the country they need to calculate following tax burdens.

- Pension Fund - 24.8\% (14.8\% for small business)

- Employment Fund $-0.1 \%$, and

- Trade Union Federation Council - 0.1\%.

Government fully regulates work visa and resident permit policy for the investors. nationals

Restrictions on employment of foreign

- The Agency on Foreign Labor Migration under the Uzbek Ministry of Labor and Social Protection sets limitations for attracting foreign personnel.
- For instance, such limitation for works under PSA is set at $20 \%$ of the total number of employees, and attracting more foreign personnel is subject to a condition that there should be no qualifying specialists in the local population.

\section{Regulatory authorities}

The principal regulatory authorities are the Cabinet of Ministers (responsible for the overall regulation of the economy), the Ministry of Finance (responsible for fiscal and taxation policy), the Central Bank(responsible for regulation of banks and monetary policy), the State Tax Committee (responsible for collection of taxes), the State Customs Committee (responsible for collection of customs payments), the Ministry of Economy (responsible for development and implementation of long-term social and economic strategies of the state) and the Ministry of Foreign Economic Relations, Investment and Trade (responsible for foreign trade and attraction of foreign investment). 


\begin{tabular}{|c|c|c|c|c|c|c|}
\hline \multirow{4}{*}{ Impact Factor: } & ISRA (India) & $=3.117$ & SIS (USA) & $=0.912$ & ICV (Poland) & $=6.630$ \\
\hline & ISI (Dubai, UAE & $=0.829$ & РИНЦ (Russia & $=\mathbf{0 . 1 5 6}$ & PIF (India) & $=1.940$ \\
\hline & GIF (Australia) & $=0.564$ & ESJI (KZ) & $=8.716$ & IBI (India) & $=4.260$ \\
\hline & JIF & $=1.500$ & SJIF (Morocco & $=5.667$ & OAJI (USA) & $=0.350$ \\
\hline
\end{tabular}

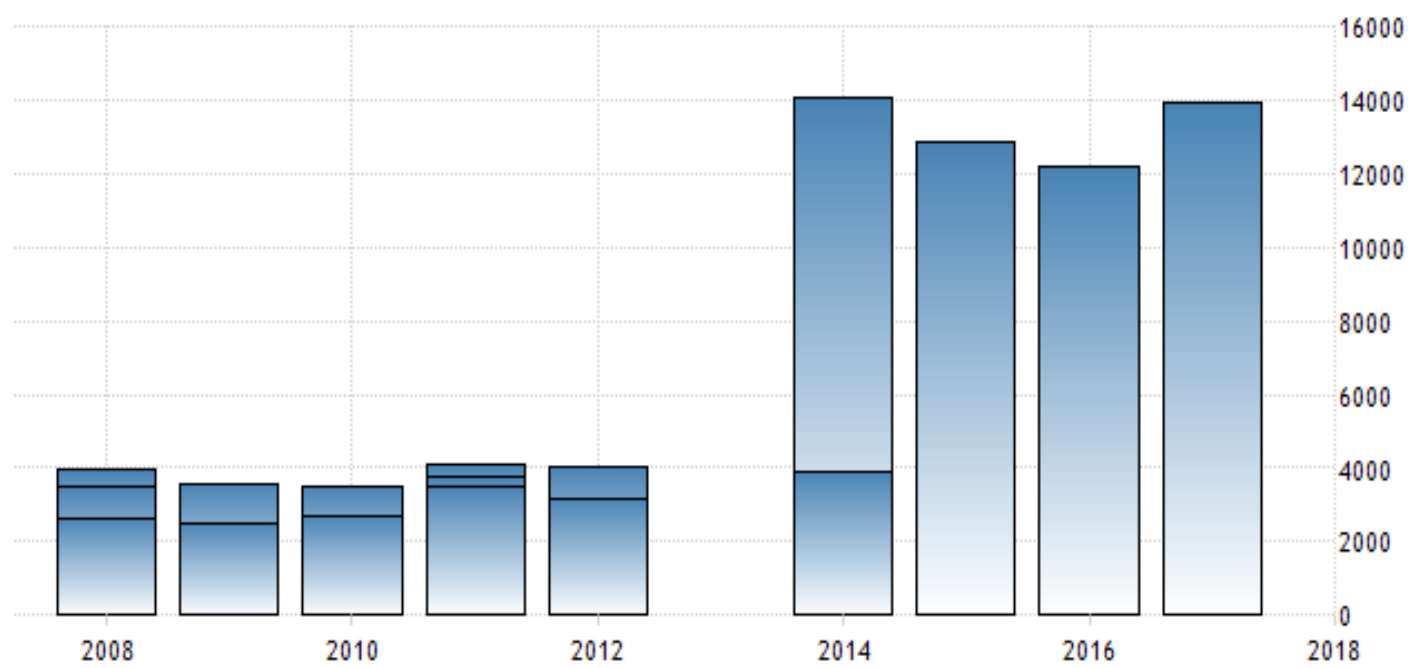

Figure 6. Uzbekistan Exports (2008-2018)

Source: Official data of trading economics

The next statistical analysis by Trading Economics exports in Uzbekistan increased to 13953 USD Million in 2017 from 12178.70 USD Million in 2016. Exports in Uzbekistan averaged 4200.85 USD Million from 2006 until 2017, reaching an all-time high of 14084 USD Million in 2014 and a record low of 1386.80 USD Million in 2006.

Incentives for carrying out export activities

Enterprises exporting goods (services) of their own production for freely convertible currency may apply reduced rates of corporate income tax as follows:
- If export total sales $15 \%$ to $30 \%$, the effective rate shall be reduced by $30 \%$.

- If export total sales is $30 \%$ or more, the effective tax rate reduced by $50 \%$.

This incentive is applied likewise in regards to property tax. Thus:

- If export ranges from $15 \%$ to $30 \%$, the property tax rate is reduced by $30 \%$.

- If export ranges from $30 \%$ and higher, the property tax is reduced by $50 \%$.

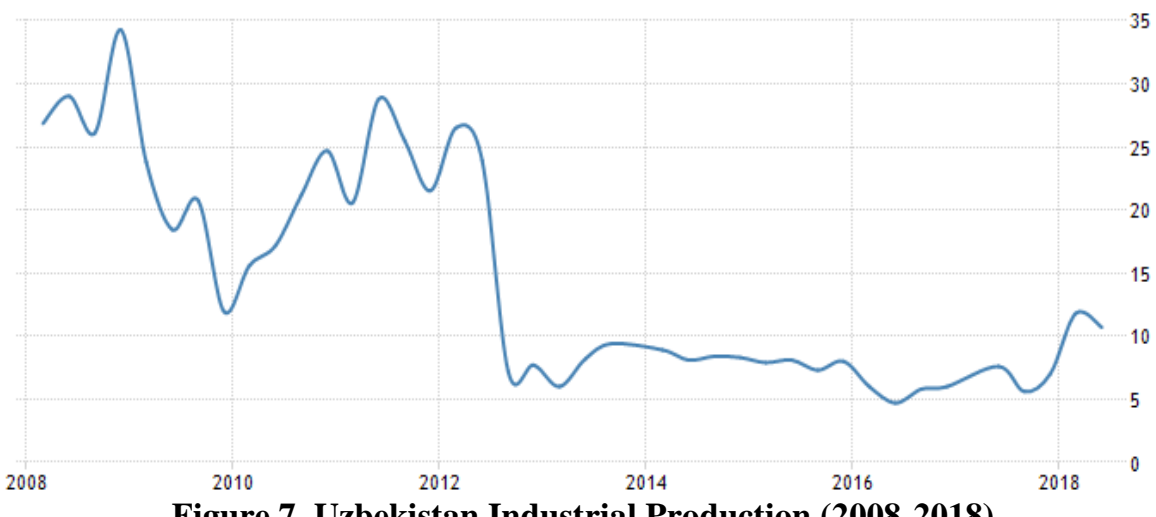

Figure 7. Uzbekistan Industrial Production (2008-2018)

Source: Official data of trading economics

Foreign direct investment to the industrial section is going very fast as above diagram shows Industrial Production in Uzbekistan increased 10.70 percent in the second quarter of 2018 over the same quarter in the previous year. Industrial Production in
Uzbekistan averaged 18.77 percent from 2004 until 2018 , reaching an all-time high of 41.12 percent in the second quarter of 2006 and a record low of 4.70 percent in the second quarter of 2016. 


\begin{tabular}{|c|c|c|c|c|c|c|}
\hline \multirow{4}{*}{ Impact Factor: } & ISRA (India) & $=3.117$ & SIS (USA) & $=0.912$ & ICV (Poland) & $=6.630$ \\
\hline & ISI (Dubai, UAE & $=0.829$ & РИНЦ (Russia & $=\mathbf{0 . 1 5 6}$ & PIF (India) & $=1.940$ \\
\hline & GIF (Australia) & $=0.564$ & ESJI (KZ) & $=8.716$ & IBI (India) & $=4.260$ \\
\hline & JIF & $=1.500$ & SJIF (Morocco & $=5.667$ & OAJI (USA) & $=0.350$ \\
\hline
\end{tabular}

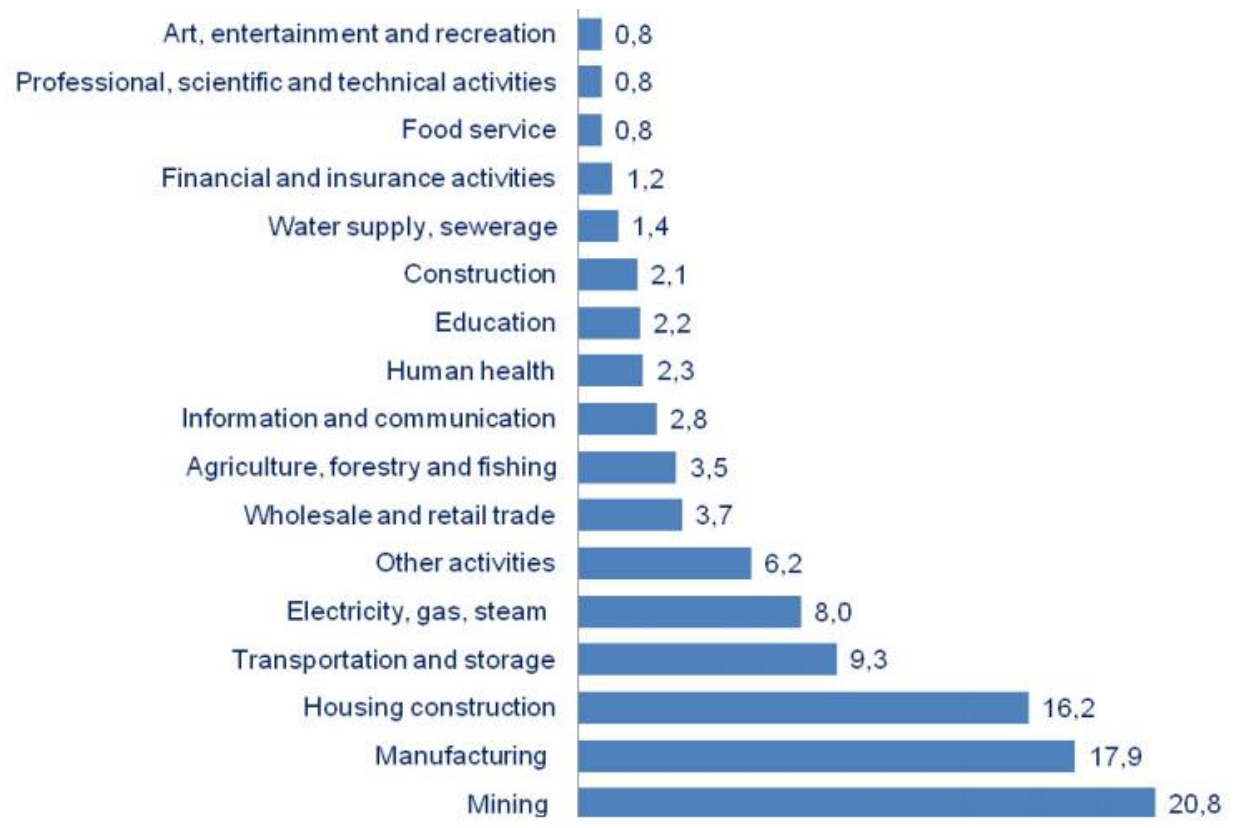

Figure 8.Investments in fixed capital by economic activity in 2017 (as\% of total)

\section{Source: Official data of stat.uz}

Compared to 2016, the share of investments in the fixed capital of the mining industry increased by 5.9 percentage points of the total volume of investments. Of which: extraction of crude oil and natural gas by 4.3 percentage points, extraction of metal ores by 0.6 percentage points.

Enterprises attracting private foreign investments are exempt from corporate income tax, property tax, infrastructure development tax, unified tax payment (for micro-firms and small enterprises), as well as contributions to the Republican Road Fund. Exemption is applicable to main business activity only.
The above taxes incentives are granted if the following, without limitation, conditions are met as reports PWC 2017:

- the enterprises are located in any city or rural area settlement of Uzbekistan except Tashkent region and Tashkent city

- share of foreign capital of enterprises should not be less than $33 \%$

- investment should be made in hard currency or new/modern technological equipment, and not less than $50 \%$ of the respective tax savings should be reinvested for further development of enterprises.

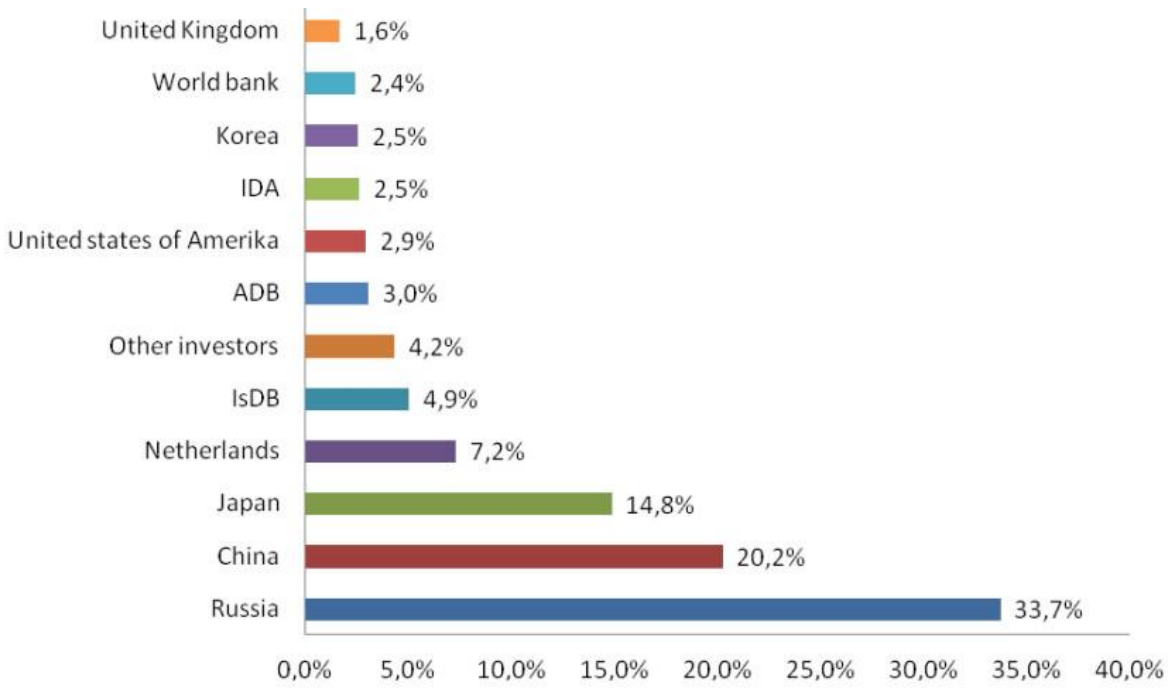

Figure 9. Share of foreign investors in total volume of foreign investments and credits in 2017

Source: Official data of stat.uz 


\begin{tabular}{|c|c|c|c|c|c|c|}
\hline \multirow{4}{*}{ Impact Factor: } & ISRA (India) & $=3.117$ & SIS (USA) & $=0.912$ & ICV (Poland) & $=6.630$ \\
\hline & ISI (Dubai, UAE & $=0.829$ & РИНЦ (Russia & $=0.156$ & PIF (India) & $=1.940$ \\
\hline & GIF (Australia) & $=0.564$ & ESJI (KZ) & $=8.716$ & IBI (India) & $=4.260$ \\
\hline & JIF & $=1.500$ & SJIF (Morocco & $=5.667$ & OAJI (USA) & $=0.350$ \\
\hline
\end{tabular}

In conclusion, Uzbekistan is the considerable as emerging markets in continent. Reforms by the government are directed professional and transparency cooperation with many international institutions, such as societies and organizations. We hope in shortly investment attractiveness will give its enormous effects by productivity and efficiency in regions, sectors and companies. The government is closely scrutinizing all foreign investment, focusing on the sectors that it considers strategic, such as mining, cotton processing, oil and gas refining and transportation. There is no single and transparent screening mechanism, and some elements of the legal framework are intended to protect the domestic industry and restrict competition from abroad. The government also uses licenses as a tool to control companies in various important sectors such as energy, telecommunications, wholesale and tourism.

\section{References:}

1. (n.d.). Retrieved 2019, from http://www.uzbekistan.nsk.ru/index.php?option $=$ com_content $\&$ view $=$ article $\&$ id $=57: 2010-04-$ 13-14-20-57\&catid=25:2010-04-13-14-2629\&Itemid $=34$

2. (n.d.). Retrieved 2019, from https://stat.uz/en/435-analiticheskie-materialyen1/2080-innovation-activity-of-enterprisesand-organizations

3. (n.d.). Retrieved 2019, from https://www.adb.org/documents/uzbekistancountry-operations-business-plan-2018-2020

4. (n.d.). Retrieved 2019, from https://www.pwc.com/uz/en/assets/pdf/dbg

5. (n.d.). Guide to doing business and investing in Uzbekistan2016 edition, PWC, page 7.

6. (n.d.). Retrieved 2019, from http://www.worldbank.org/en/country/uzbekista n/overview\#4

7. (n.d.). Retrieved 2019, from http://www.worldbank.org/en/country/uzbekista n/overview\#3
8. (n.d.). Retrieved 2019, from http://www.uz.undp.org/content/uzbekistan/ru/h ome/presscenter/articles/2017/12/26/how-topromote-and-facilitate-investment-inuzbekistan-.html

9. (n.d.). Retrieved 2019, from https://tradingeconomics.com/uzbekistan/emplo yed-persons

10. (2017). Speech of the President of Uzbekistan at the 72nd Session of the UN.

11. (2017). President's speech of annual report at the end of 2017.

12. (n.d.). Law of the Republic of Uzbekistan on Investment Activities. 1999, 2014, 2017.

13. (2018). The Law on Guarantees and the Protection of Rights of Foreign Investors.

14. (2017). World Investment Report. UNICTAD.

15. (2018). World Bank Group Flagship Report, Doing Business 2018.

16. (2017). World Bank Overview 2017.

17. (2016). PWC Guide to doing business and investing in Uzbekistan 2016 edition. 